\title{
EDITORIAL
}

\section{The Law of the Sea and the late Shirley Amerasinghe}

$\mathrm{W}$ ith the oceans and salt seas occupying nearly three-quarters of the surface of our globe, being traditionally used for transport on a great scale, and containing or covering as they do a substantial proportion of the world's feeding-potential and mineral wealth, the enactment and enforcement of proper laws to govern them and their employment clearly constitute one of the most important issues of our day. It becomes ever more urgent as human population-pressures build up and, with them, the incidence of pollution and resource-depletion.

In 1973 the United Nations General Assembly approved a proposal, long advocated by a group led by the then Ambassador from Malta, Dr Arvid Pardo, of a United Nations Third Conference on the Law of the Sea, those of 1958 and 1960, held in Geneva, having 'accentuated the need for a new and generally acceptable Convention'. This third such conference was instituted forthwith and continued, falteringly at times, through nine full sessions until late August of 1980 , when it seemed that a tenth session of 6-7 weeks in the spring of 1981 , followed by a brief final session for the signing of an actual 'Convention on the Law of the Sea', should suffice to terminate the entire Conference and allow its outcome to proceed. (At present there is merely a 'Draft Convention on the Law of the Sea (Informal Text)', of xix + $180 \mathrm{pp}$., that is still a negotiating text rather than a finally negotiated one.)

By many biologists and others, the suitability of the proposed title of the emanating 'International Sea-bed Authority', and the wisdom of placing it most likely in Jamaica or Fiji, may well be questioned. But such an Authority, dealing globally with living as well as mineral resources, should at least be better than the situation to date of having none at all, and doubtless if it does not work satisfactorily from one base it will be made to do so from another. For the entire theme is far too vitally important for an alert world to allow it to lapse through the apathy of officialdom or falling prey to sectarian interests.

That the United Nations' marathon Third Conference on the Law of the Sea has now at last come within sight of a satisfactory conclusion is largely due to the skilful guidance of one man, who coaxed it throughout its life to date of nine long and often multiple transatlantic sessions extending over seven years. This was the former Ambassador of Ceylon and President of the United Nations General Assembly, Hamilton Shirley Amerasinghe. Having been Chairman of the UN Committee on the Peaceful Uses of the Sea Bed and Ocean Floor beyond the Limits of National Jurisdiction from its inception in 1968, Ambassador Amerasinghe seemed the natural choice as President of this major UN Third Conference on the Law of the Sea.

Following the latest session, at which he performed, as we were privileged to witness, with exemplary patience and aplomb, he returned from Geneva to New York, and died there on 4 December 1980 following a stroke from which he did not regain consciousness - a devastating loss to his friends and indeed to the world. As we terminated our appreciation in The Times of London and have their encouragement to quote, '... he told us privately in late August..., just after the termination in Geneva of the latest session, that he fully expected a brief one next spring in New York "to see us well through". It is most ardently to be hoped that this will indeed come about, and prove at once a major advance towards world stability and a lasting memorial to this patiently courageous man.'

Dare we suggest that the best chance for the full success of this vital Conference on the Law of the Sea might well come through the Secretary-General of the United Nations himself presiding at these remaining sessions, bringing thereto the immense prestige of his office and at the same time emphasizing their paramount importance?

N.P.

\section{A Plea for the World's Forests}

$\mathrm{D}$ r Norman Myers's article on 'The Present Status and Future Prospects of Tropical Moist Forests', published in the Summer issue of Environmental Conservation (Vol. 7, No. 2, pp. 101-14,1980), has been read with intense interest as it throws full light on the subject of conserving the remaining tropical moist forests which we all realize to be of paramount importance. The article contains practically everything which the layman wants to know, and its presentation is exemplary. But may I be allowed to say how the problem now appears to a layman?

Even though the damage occurs in far-away countries, it is clear that the responsibility is basically ours. Dr Myers 'wisely avoids for these countries the misleading appellation of 'developing', but prefers to talk of the 'Third World'. I find it equally unsatisfactory to refer to us as 'developed'; so as the existence of a 'Third World' implies that of a 'First' (the communist countries, which incidentally appear to be little involved in TMF problems, are presumably the 'Second'), I assume that the culprits can be referred to as the 'First World'.

A look at the extensive list of references given by Dr Myers shows first of all that there is not a single one from the 'Second World', while for every one from the 'Third World' there are no less than seven from the 'First' (though curiously enough no Japanese). It thus seems clear that the 'First World' acknowledges the problem as its own.

Roughly speaking the damage to the TMF seems attributable to four agents: (1) timber exploitation, (2) cattle ranching, (3) forest farming, and (4) fuel gathering. The 'Third World' would seem to be responsible for the last two; however, the greater part of the damage is shown to arise out of the action of our timber exploiters in opening up ways into the forest. Furthermore, inasmuch as the farming and gathering result from the pressure of population, one is bound to reflect that this pressure is the direct result of the 'First World's' interference with the processes of Nature which, ever since the dawn of history, had operated to keep populations down to manageable levels. 
In any case it is the 'First World's' duty to save the TMF, and to blame lumber exploiters or other multinationals concerned for their disappearance is perhaps as absurd as it would be to blame oil companies for people's desire to drive motor-cars. The real culprit is all of us who insist on getting the goods, whatever they are, which we derive from tropical lumber. I cannot believe there is any sense in trying to persuade people to give up these things; so the first question is whether some substitute does not exist for tropical hardwoods. It may be that some other means can be found or devised of satisfying our needs. This would make governmental action much easier; for while politicians can only lose votes by preaching retrenchment, they can gain some by encouraging new industries.

Meanwhile a valuable part-solution would seem to lie along the lines to which Dr Myers alludes when he says: 'With greater care, the damage could be reduced by a half'. Could it not be that, with far greater care, the damage might be reduced by much more than half? It is likely that lumber companies will not be keen to see those forests disappear, from which they have reaped such profit in the past and could continue, with due care, to reap in future; also, they may well wish to avoid being pointed at as wreckers of the Biosphere. Surely, besides that of world public opinion, legal pressure should be brought to bear on them to discontinue wasteful methods!

By comparison with what I see happening in other fields, I would suggest that one hour spent on discussion with representatives of lumber companies at a technical level, would be worth many spent in issuing warnings and drafting resolutions.

It may well be that those who know the facts also know that such a course of action is impracticable to follow; however, I cannot help deriving hope from the history of our own forests. Foresters today consider many of the practices of a hundred years ago as pure wreckage, from which some of our forests are barely recovering even now. In most of the 'First World' the forest situation has, I believe, ceased to deteriorate; in fact, in several enlightened countries it is reported to be improving, and so are the yields from their forests.

Roger de Candolle* 41 chemin du Vallon 1224 Chêne-Bougeries Geneva, Switzerland.

\section{Evening Storm}

Lightning.

Flickering twilights in the west.

(Must be thirty miles at best.)

Closer.

Welding up a black cloud mass.

(Need some rain on my dry grass.)

Thunder.

Grumbling at the evening hour,

Working up to greater power.

Hear the wind in distant treetops!

There's a spattering of raindrops.

Now the downdraft comes in lashes,

Now the thunder really crashes!

Birches nearly double bend,

Oak leaves fly by on the wind.

Black as hell and bright as day.

Now the torrent's on its way.
Sheets of water from the eaves,

Silver rivulets from leaves.

Rushing rivers in the gutters -

Still the thunder booms and stutters.

Seems to be a little lighter.

West is now a little brighter.

Now it's stopped.

Still dripping wet.

But there'll be

Some more, I bet.

Hear it?

Reid A. Bryson, Director

Institute for Environmental Studies

University of Wisconsin

1225 West Dayton Street

Madison

Wisconsin 53706, USA.

\section{Chipko: A Means of Environmental Conservation}

The devastating flood of Alakananda and its tributaries, which practically swept away the village of Belacuchi, several tourist buses, five major bridges, 13 suspension bridges, two log bridges, hundreds of head of cattle, and several hundred million rupees' worth of timber and fuel, finally awakened the people of the Chamoli district to the dangers of deforestation. Every year thereafter the district witnessed increasingly heavy

*Quite apart from being a direct descendent of the great line of botanists whose name he bears, Monsieur de Candolle is President of the International Dendrology Society. - Ed. 